\title{
VNÍMAT, MYSLET, ČÍST - PERCEPTUÁLNÍ A KONCEPTUÁLNÍ MOŽNOSTI ANALÝZY UMĚNÍ
}

\author{
ELIŠKA KORYNTOVÁ \\ Ústav pro dějiny umění, Filozofická fakulta Univerzity Karlovy \\ E-mail: ela.koryntova@gmail.com
}

Toto číslo časopisu Studia Historiae Artium z ediční řady Acta philosophica et historica je zčásti věnováno prríspěvkům, které zazněly na doktorandské konferenci Vnímat, myslet, čist - perceptuální a konceptuální možnosti analýzy umění pořádané Ústavem pro dějiny umění FF UK v Galerii Tranzitdisplay ve dnech 19. 9. - 20.9. 2017. Druhá část letošního svazku dává vedle uměleckohistorických textů prostor i pro hlasy z jiných oborů (konkrétně z egyptologie, estetiky a neurologie).

Naším cílem bylo aktualizovat pojetí umění jako svébytného druhu jazyka a otevřít řadu otázek, které se týkají analýzy vnímání a vztahu mezi obrazem a textem. V čem se jazyk umění odlišuje od jazyka verbálního a co s ním má společné? Každý historik umění se během své praxe dostal do situace, kdy se mu nedaří slovy vyjádřit to, co považuje na uměleckém díle za podstatné. Verbální řeč má své limity - představte si, že máte nevidomému popsat, jak vypadá modrá barva. Můžete se pustit do nekonečného výčtu všech věci na světě, které mají modrou barvu, můžete popsat barvu z fyzikálního hlediska, můžete se pokusit vyjádřit, co při pozorování modré barvy cítíte - žádný popis však není schopen zrakový vjem modré barvy nahradit. Umění je prostředkem komunikace, na rozdíl od verbální řeči však nejsou jeho primární doménou vyjádření slova, ale fenomény vnímatelné zrakem, hmatem, pohybem, tělesnou orientací v prostoru apod. Myšlenky, které stojí v pozadí vzniku uměleckých děl, lze vyjádřit textuálně - přesto nelze umělecká díla chápat jakou pouhé ilustrace verbálně formulovaných myšlenek. Umění má své vlastní prostředky vyjádření - podle Susanne Langerové, jejímuž dílu se věnuje v tomto sborníku Tereza Hadravová, je smyslem umění jeho schopnost rozšíriit pole lidské komunikace za hranice běžné verbální řeči.

V umění se perceptuální a konceptuální složka prolínají tak, že nelze jednu oddělit od druhé. Metodologie dějin umění od svých počátků mezi oběma složkami osciluje. (Že jiné kulturní okruhy nemusí obraz a text tak př́isně oddělovat, ukazuje příspěvek Hany Benešovské, věnovaný problematice semiosis a mimesis v umění starého Egypta.) $\mathrm{V}$ poslední době řada autorů zdůrazňuje, že obraz není textem nahraditelný a vztah mezi perceptuální a konceptuální stránkou umění promýšlí jako dialektický. Podle Michaela Podra nelze obsah uměleckého díla oddělit od jeho formy: dva obrazy s totožným výjevem podané různým malířským rukopisem totiž budeme interpretovat jinak. ${ }^{1}$ Proti ostrému rozdělování perceptuální a konceptuální stránky umění se vymezuje David Summers, podle kterého je „lingvistický imperialismus" pouze krátkodobou epizodou

1 Michael Podro, Znázornění a zlaté tele, in: Ladislav Kesner, Vizuální teorie. Současné angloamerické myšlení o výtvarných dílech, Jinočany 2005, s. 91-119. 
v dějinách umění. ${ }^{2}$ (Myšlenky Davida Summerse aktualizoval na konferenci Jiř́i Kroupa v závěru svého příspěvku Curieux, Erudita, Cicerone: historik umění v Arkádii, který pronesl na vyžádání organizátorů jako host.) Martin Kemp se domnívá, že význam díla nemusí být jednoduše přeložitelný do slov, protože slovy popisujeme pouze ty aspekty obrazů, které jsou skrze verbální jazyk postižitelné. Podle Kempa není jazyk výtvarného umění pouze kulturně podmíněný, ale vychází z našeho tělesného vnímání a lze v něm najít určité univerzální rysy. ${ }^{3}$ Dalibor Veselý si v úvodu své knihy Architektura ve věku rozdělené reprezentace postěžoval, že o architektuře se dnes prŕliš mnoho píše ${ }^{4}$ - tímto nadsazeným tvrzením chtěl poukázat na skutečnost, že architekti by se měli soustředit na to, jak kýžený význam vloží do realizované stavby, než jak ho dodatečně formulují verbálně. Architektura by podle Veselého měla „komunikovat spíše vizuálně než slovy“5 a na diváka by měla působit svým "tichým jazykem“. 6

Jak ale může historik umění interpretovat „tichý jazyk“ uměleckých děl jinak než slovy? Měli bychom snad analyzovat umění skrze výtvarnou tvorbu, jak zaznělo na diskuzi konference? Jakýkoli autor zdůrazňující primární postavení smyslového vnímání se dostává do paradoxní situace - své přesvědčení o dominantní úloze smyslů vyjadřuje pomocí verbální řcči. Paradoxní povahu takového počínání přesně vystihl Miroslav Petříček: „Kdybychom se snažili hledat takové myšlení obrazem, které není čtením obrazu, už bychom si na samém začátku vážně protiřečili: o obrazech mluvíme i tehdy, když se chceme zaměrit na vidění obrazů. "7 Poznání, že jazykem nelze zprostředkovat všechny nuance výtvarného umění, by však nemělo vést ke skepsi. Tvrzení, že tváří tvář „nevýslovnému“ je lepší mlčet, lze brát pouze jako rétorickou figuru. Snaha překonat propast, která stojí mezi jazykem a nevyslovitelnou zkušeností, má v evropském myšlení svou dlouhou tradici v díle teologů a mystických básníků. ${ }^{8}$ „Není ani bytím ani věčností ani časem. [...] Není tmou ani světlem ani omylem ani pravdou, “ rŕká Dionýsios Aeropagita, když vyjmenovává vše, co nelze ztotožnit s Bohem, a dokládá tak, že i negace mưže být formou přitakání. ${ }^{9}$ Ačkoli se různé autority napříč staletími shodují v tom, že Boha nelze ztotožnit se slovy či obrazy, která k jeho popisu používáme, všichni mystičtí básníci tyto prostředky používají, aby skrze ně tlumočili svou extatickou zkušenost. Mnozí tento paradoxní úkol chápou za svůj životní cíl - slovy Williama Blakea, mistra básně i obrazu: „Neustanu ve svém velkém úkolu otvírat věčné světy. "10 Jak se $\mathrm{k}$ Bohu přiblížit, když se zavedené symbolické formy rozvolní a jejich čtenáři tak schází „slovník“ (ve smyslu společenského konsenzu) k jejich dešifrování, ukazuje příspěvek Hany Lamatové věnovaný konceptuálnímu zobrazení kř́ižové cesty ve 20. století.

2 David Summers, Reálná metafora: pokus o definici „konceptuálního“ zobrazení, in: Kesner (pozn. 1), s. 154.

3 Martin Kemp, Visualizations. The Nature Book of Art and Science, Oxford 2000, s. 1.

4 Dalibor Veselý, Architektura ve věku rozdělené reprezantace - Problém tvořivosti ve stínu produkce, Praha 2008, s. 11.

5 Ibidem.

6 Ibidem, s. 63.

7 Miroslav Petř́ček, Myšlení obrazem: Prưvodce současným filosofickým myšlením pro středně nepokročilé, Praha 2009, s. 10.

8 Evelyn Underhill, Mystika. Podstata a cesta duchovního vědomí, Praha 2004, s. 110-111.

9 Dionysios Aeropagita, Listy O mystické teologii, Praha 2005, s. 179-181.

10 Underhill (pozn. 8), s. 273. 
Historik umění sice není mystik, ale je vědec, nicméně i v jeho práci přichází ke slovu intuice a schopnost vcítění. Intuicí jako předpokladem pro „anachronické“ dějiny umění se zabývá příspěvek Evy Skopalové s tajuplným názvem Třetí oko historika umění. Radikálně odlišný přístup, jak interpretovat umění, představuje Petr Adámek v článku věnovaném statisticky analytické metodě „eye-trackingu“využívané v neurologii, př̀i níž přístroj zaznamenává pohyb lidského oka během sledování obrazu. Kontrast obou př́ístupů nás přivádí k problematice „objektivního“ a „subjektivního“ popisu světa, které bývají často chápány jako nesmiřitelné protiklady, ačkoli jsou spíše provázanými modalitami lidského poznání světa.

Nevyslovitelné aspekty umění nelze sice řečí pochytit, ale vždy je lze v náznacích přiblížit - čtenář textu porozumí na základě srovnávání se svou vlastní životní zkušeností. (Při četbě příspěvku Zdislavy Melicharové Ryantové věnovanému popisu akčního umění nás dokonce může napadnout, že formálně úsporný popis může někdy skutečnost zpřístupnit naléhavěji než obrazově košaté metafory.) Vhodně zvolená slova navedou čtenáře i k vnímání toho, co přímo v textu zmíněné není. Význam věty se utváří až v mysli čtenáře, který pochopí i to, co je v textu naznačené, ale ne přímo obsažené: „Řeč není žádná uzavřená oblast vyslovitelného, kolem níz by byly jiné oblasti nevýslovného, nýbrž ona zahrnuje všecko. "11 Člověk má schopnost skrze řeč pochytit i ty aspekty lidské zkušenosti, které se řeči vzpírají a nejen to, celý proces může i vědomě reflektovat. Následující metodologicky různorodé prŕíspěvky ukazují, že vztah mezi obrazem a textem je nevyčerpatelný a zasluhuje si obsáhlou reflexi.

11 Hans-Georg Gadamer, Člověk a ř č́, Praha 1999, s. 28. 